\title{
Günümüzün Dijitalleşen İşletmelerinde Yeni Liderlik Ve Motivasyon Modelleri Üzerine Karşılaştırmalı Bir Araştırma
}

DOI: $10.26466 /$ opus.699386

*

\section{Bașak Demiryumruk Dikici*}

* Doktora Öğrencisi, İstanbul Aydın Üniversitesi, İşletme Fakültesi, İstanbul/Türkiye E-Posta: basak.demiryumruk@gmail.com

ORCID: $0000-0002-1431-5172$

Öz

Günümüz şirketlerinin amacı potansiyeli yüksek çalışanları örgütlerine çekmek, onları en verimli şekilde çalışır halde örgütte tutmak, örgütün hedefleri doğrultusunda en üst verimlilikte ve karlılıkta çalışarak pay sahiplerine ve paydaşlarına sürdürülebilir şekilde katkı sunmaktır. Bu nedenle şirketin amaç ve hedeflerine direkt etkisi olduğu belirlenmiş motivasyon ve liderlik modelleri önemini korumakta ve korumaya devam etmektedir. Bu anlamda küresel ortamlarda faaliyette bulunan işletmelerin dijitalleşmesi hayati bir husus iken dijitalleşme süreçlerinde motivasyon ve liderlik modellerinin nasıl şekillendiği de son derece önemlidir. Yüz yılı aşkın süredir üretim yapan, dünyanın farklı noktalarında sadece dağıtım ağları ile değil üretim tesisleriyle de önemli yatırımları bulunan $A, B$ ve C Firmaları da bu yönleri itibariyle bu araştırmada yer almıştır. Çalışmada dijitalleşmenin firmalara getirdiği avantajlar ve zorluklar, Endüstri 4.0 ve dijitalleşme ile değişen liderlik prensipleri ve bunların çalışan motivasyonuna nasıl yansıdığı şirket çalışanlarına yapılan anketlerle incelenerek ele alınmıştır. Bu çalışma günümüzün dijitalleşen işletmelerinde yeni dünyanın gerektirdiği liderlik prensiplerini inceleyerek şirketin benimsediği ve diğer modern liderlik davranışlarının çalışanların motivasyonlarına etkisini ele almıştır.

Anahtar Kelimeler: Dijitalleşme, endüstri 4.0, liderlik, motivasyon 


\title{
A Comparative Research on New Leadership and Motivation Models in Digitalized Companies
}

\begin{abstract}
The aim of today's companies is to attract employees with high potential to their organizations, to keep them working in the most efficient manner, to work in the highest efficiency and profitability in line with the objectives of the organization and to contribute to the shareholders and stakeholders in a sustainable way. Therefore, the culture, motivation, employee engagement and leadership models that have a direct impact on the company's goals and objectives remain and maintain their importance. In this sense, while digitalization of businesses operating in global environments is a vital issue, it is extremely important how motivation and leadership models are shaped in digitalization processes. The companies $A, B$ and $C$, which have been manufacturing for more than a century, and have significant investments in not only distribution networks but also in production facilities in different parts of the World is included in this study. In this study, the advantages and challenges of the digitalization, the changing principles of the industry and their reflections on motivation is examined through surveys conducted through employees. This study examines the impact of the company's adopted and other modern leadership behaviors on the motivation of employees by examining digitalized companies and the leadership principles required by the new world.
\end{abstract}

Keywords: Digitalization, Industry 4.0, leadership, motivation 


\section{Giriş}

Günümüzde önemi giderek artan globalleşme bireyleri etkilediği gibi işletmeleri de etkilemektedir. Değişen dünya, yeni ekonomi ve özellikle dijitalleşme ile birlikte şirketler farklı ülkelere yatırım yapmakta, farklı ülkeler içerisinde farklı coğrafi bölgelerde satış-pazarlama ağları kurmakta ve hatta üretim tesisleri inşa etmekteler. Farklı lokasyonlarda faaliyet gösteren bu global işletmeler bulundukları ana ülkede sağladıkları başarı oranlarını diğer lokasyonlarında da aynı seviyede tutmaya gayret ederler. Şirketler, yöneticilerin sergiledikleri liderlik modellerini, çalışan motivasyon seviyelerini ve hatta çalışan devir oranlarını belirli bir seviyede tutarak global marka olarak her noktada aynı karakteri göstermeye çalışırlar.

Günümüzün yoğun rekabet ortamında artık şirketlerinin amacı sadece üretim veya satış yapmak değil aynı zamanda potansiyeli yüksek çalışanları örgütlerine çekmek, onları en verimli şekilde çalışır halde örgütte tutmak, örgütün hedefleri doğrultusunda en üst verimlilikte ve karlılıkta çalışarak pay sahiplerine ve paydaşlarına sürdürülebilir şekilde katkı sunmak olmuştur. Bu nedenle şirketin amaç ve hedeflerine direkt etkisi olduğu belirlenmiş motivasyon ve liderlik modelleri önemini korumakta ve korumaya devam etmektedir. Artan rekabet ortamının zorluklarına bir de sürekli devinim halinde olan küresel pazarlar ve yeni üretim sistemleri girmekte dünya topyekün bir dönüşüm içinde sürekli yeniliklere sahne olmaktadır. Sürekli iş hayatı gündeminde yer alan dijitalleşme de bu yeni dünya oluşumlarının en büyük zeminlerinden biridir. Bildiğimiz gibi 18. yüzyıl sonlarında su ve buhar gücünün kullanıldığı mekanik üretim sistemleri (Endüstri 1.0) 20. yüzyıla girerken yerini elektrik gücüne ve onun yardımıyla gerçekleşen seri üretime (Endüstri 2.0) bıraktı. 1970'lere geldiğimizde ise bilgi teknolojilerinin gelişmesi ile daha otomatikleşmiş üretim sürecine geçilmiştir (Endüstri 3.0).

21. yüzyıl ise artık siber-fiziksel sistemlere dayalı üretimin yapılabildiği, nesnelerin internet üzerinden haberleşebildiği ve yönetilebildiği, otonom etkileşim ve sanallaştırmanın neredeyse her sektöre uyarlanabildiği bambaşka bir sanayi devrimini getirdi. Endüstri 4.0 olarak adlandırılan bu yeni dönemde artık teknoloji günlük hayatta ve iş hayatında geleneksel çalışma sistemlerini kökten değiştirmekte. Değişen teknolojiye ve çalışma sistemlerine ayak uydurmak için şirketlerde pek çok çalışmalar yürütülmekte. Bu dönüşümün en büyük parçası olan dijitalleşmenin yani elle toplanan verilerin ve 
mesleki süreçlerin bilgisayara ya da dijital ortama aktarılmasının önemi de giderek artırıyor. Bilgisayarların işlev güçleri sayesinde süreçler hızlanıyor; tüm verilere erişim ve kaynak yönetimi kolaylaşıyor. Tüm bu dönüşüm firmalar için sadece üretim ve diğer hizmetlerinde değil liderlik ve çalışan motivasyonu konularında da bambaşka açılımlara imkan sağlıyor. Bu değişimi yaşayan şirketlerdeki liderlik ve çalışan motivasyonu bu çalışmada kapsamlı şekilde ele alınacaktır.

\section{Şirketlerde Dijitalleşme ve Yeni Liderlik}

1800'lü yıllarda buharlı makinalar icat edilmiş ve böylece Birinci Sanayi Devrimi başlamış ve o dönemde yapılan bilimsel çalışmalarla teknolojide gelişmeler yaşanmıştır. Bu durum ise 2000'lerde Endüstri Devrimlerinin sonuncusu olan 4. Endüstri Devrimi'ni başlatmıştır. Endüstri 4.0 döneminde, yaşanan teknolojik gelişmeler çok daha huzlı ilerlemektedir. Bu gelişme, Endüstri 4.0'1 diğer sanayi devrimlerinden ayıran en önemli özelliğidir. 4. Endüstri Devrimi; devletlerde, firmalarda ve toplumun tüm alanında önemli bir dizi değişikliklerin olmasını sağlamıştır. Endüstri 4.0 kavramı, sanayideki üretim sürecinin dijital ortamla entegrasyonu ve entegrasyon sonrasinda akıllı ürünler geliştirme, verimliliği arttırılmış üretim gerçekleştirme, devamlılığı olan müşterilere ulaşma ve lojistik ağı kuvvetli olan çok boyutlu bir sistemi anlatmaktadır (Özkan, Al ve Yavuz, 2018, s.126). Endüstri 4.0 ile üretilen teknolojiler, firmaların yönetim, ekip kurma ve finansman yöntemlerini etkilemektedir. Bunun yanında dijital teknolojiler, firmaların değişim hızında ve boyutunda değişikler yaşatmaktadır (Schwab, 2017, s. 59). Endüstri 4.0 dönemi ile birlikte çalışan kesim de hılı ve kolay bir şekilde bilgiye ulaşabilmiş, büyük miktarlardaki veriler kolaylıkla bir yerden bir yere aktarılabilmiştir.

Endüstri 4.0 dönemindeki firmaların değişim ve gelişmeleri şunlardır (Özkan, Al ve Yavuz, 2018, s. 126): Yönetim, imajı iyileştirme, misyon ve vizyonu iyileştirme ve devam etme, organizasyonel yapıyı iyileştirme ve ekip çalışmasını ön plana çıkarma, çalışanların memnuniyetini artırma, finansal bir bakış açısıyla, büyümeyi ve kârı arttırmak, sermaye çekmek ve yeni yatırımlar yapmak ve ortak ve hissedarlara daha fazla kar vermek, aynı zamanda da şirket varlığını ve ödeme gücünü korumak, maliyet açısından, tüm maliyetlerin kontrolü ve azaltılması ile daha düşük maliyetli ama daha kaliteli ve uygun fiyatların üretimi, üretimde insan-makine işbirliğini sağlamak ve seri 
üretimi arttırmak, yani verimliliği ve üretkenliği artırmak, optimum üretimi gerçekleştirerek sürekliliği sağlamak, satış ve pazarlama açısından, üstün rekabet gücü elde ederek veya pazara hükmederek pazar payını arttırmak, müşteri istek ve ihtiyaçlarını hem kalite hem de fiyat, satış sonrası hizmetler (servis, dağıtım, yedek parça ve değişim hizmetleri) ve her türlü faaliyetlerin geliştirilmesi, araştırma ve geliştirme faaliyetlerine, bilişim teknolojilerinden daha çok önem verilmektedir ve daha fazla yararlanmaktadır.

Çalışma ortamındaki yaygın dijitalleşme ve artan teknoloji kullanımı, firmalarda üretkenliğin artmasında, maliyet tasarrufu yapılmasında ve karmaşıklaşan pazarda esneklik ve uyum kabiliyeti kazanılmasında rol oynamaktadır. Firmalar böylelikle evrensel insan kaynağı ile uluslararası düzeyde işbirlikleri yapabilmekte ve işgörenler internet erişiminin olduğu her yerde dünyanın her noktasından çalışmayı sürdürebilmektedir. Dijitalleşmenin kazandırdığı yeniliklerden biri de farklı zaman diliminde ve ülkelerdeki çalışanların ve yöneticilerin, Skype, e-posta ve bulut depolama teknolojileri ile uzaktan çalışabilmesidir. Bu sayede firmalar müşteri ziyaretleri veya farklı çalışma gruplarıyla yapılan işler için pahalı yolculuklara bütçe ayırma gereksinimi duymamaktadırlar. Dijitalleşmenin firmalara sağladığı fırsatlar, işgörenler ve firmaların fiziki bölgelere ve işbirliği içinde olunan pazarlara olan zorunlu bağımlılığını ortadan kaldırmaktadır. Firmalar kurulduğu yerde kalma mecburiyeti hissetmeden çalışmak istedikleri ortamlara rahatlıkla ulaşabilmektedir. Akıllı telefonlar, tabletler ve diğer mobil cihazlar çalışanların herhangi bir yerden iş yapabilmesini, işgörenlerin çalıştıkları, iş yaptıkları kişilerle bağlantıda kalabilmelerini, işbirliğinde bulunabilmelerini sağlamaktadır (Tarıyan, 2018, s. 71). Dijitalleşme dönemi çalışma ortamında yeni liderlik yaklaşımlarını da gündeme getirdi. Bir sonraki başlık altında değerlendirilecek konu ile bu yeni yaklaşımlar ele alınacaktır.

\section{Dijitalleşen İş Ortamında Yeni Liderlik Uygulamaları}

Gelişen dünyada, bu gelişmelerden olumsuz etkilenen insan ilişkilerinin olduğu düşünülmektedir. Halbuki tüm değişimler ve gelişimler de insanlar tarafından olmaktadır. Tarihte bazı insanlar isminden bahsettirebilirken bazılarıysa sadece kendilerine verilen görevleri yaparak hayattan ayrılmışlardır. Aynı zamanda insanlar birbirlerine karşı üstünlük sağlamak için savaşmışlar. 
Bu üstünlük savaşı siyasi, askeri ve ekonomik alanlarda kendisini göstermiştir. Bu savaşta başarının elde edilmesinde rolleri olan mücadele önderlerinin liderlik başarısına bağlıdır. 21. yüzyıl insanlarının hayatında etken rolü olan bilgi ve teknoloji çağı, her geçen gün değişen, gelişen ve bu durumun hızına yetişilemeyen bir çağdır. Bu değişim ve gelişimler insanların kendilerini takip eden liderlerin özelliklerini etkilemiştir. Önceleri otokratik ve egemensel bir liderlik anlayışı varken iken Birinci Sanayi Devrimi dönemi (Buhar Gücü Keşfi) ile başlayan ve Endüstri 4.0 döneminde kadar daha bilimsel bir liderlik anlayışına geçilmiştir. Bu dönemde liderlik tanımı çok değişikliğe uğrayarak, modern yönetim tarzlarıyla birlikte şeffaf bir yapıya dönüşerek daha demokratik ve katılımcı olmaktadır.

\section{Liderlik Teorileri}

\section{Değerlere Dayah Liderlik}

Değerler, inançların, olaylara karşı gösterilen tutumların, hissedilen duyguların ve çeşitli oluşumlara verilen yanıtların bir araya gelmiş halidir. İnsanlar açık veya gizli bir şekilde, olaylara, fikirlere veya nesnelere iyi veya kötü, uygun veya uygunsuz, doğru veya yanlış gibi değerler yükler. İş hayatıyla ilgili bu tür hisler ve düşüncelerse kurumsal değerleri ifade eder. Günümüzde, değerlerle yönetim tarzı, değerlere dayalı liderlik gibi kavramlar giderek daha fazla kullanılmaya başlamıştır. Kişisel ve kurumsal değerler, insanların yetiştirilme tarzları, yaşam tecrübeleri, dini inançları, çalışma arkadaşları ve sosyal çevreleri ile şekillenir. İnsanlar dünyaya neyin doğru neyin yanlış olduğunu anlıyor olarak gelmemektedir.

Değerlerin en önemli işlevi, insanlara bireysel ve kurumsal gereksinimleri karşılayacak standartlar sağlamak, onların özgüven ve motivasyon duygularını geliştirmektir. Belli değerlere bağlılık, insanların güvenini ve kendilerine olan saygısını arttırmaktadır. Ahlak ve beceriler için sosyal ve kurumsal standartlara sahip olmak, başkalarının saygı duymasını da sağlamaktadır. Değerlere dayalı liderlik, insanlara değerlerini hatırlatmaktadır ve neyin gizlendiğini netleştirmektedir. Gerekirse önemli ve öncelikli değerlerin ortaya çıkarılmasını ve yeniden düzenlenmesini sağlamaktadır. Böyle bir liderlik tarzına sahip insanlar, inançlarını ve değerlerini sıralamaktadır ve öncelik sırasına 
koymaktadır, davranışlarını ve varsayımlarını yönlendiren değerler hakkında tam, doğru ve tutarlı bir bütünlük sağlamaktadır.

Taylor (2010, s. 7) değer temelli liderliği, "kişisel kazanç odaklı olmadan, tedarikçilere, ortaklara, müşterilere ve firmaya değer getiren bir liderlik felsefesi" olarak tanımlamıştır. Başka bir tanımsa değerlere dayalı liderlik; liderüye ilişkisinde ortak değerlere odaklanan bir liderlik yaklaşımıdır (Maier ve ark., 2015, s. 384). Yönetim kuramcıları tarafından kurumsal liderlerin ahlak ve etik gereksinimleri birçok kez ele alınmıştır. Değer merkezli liderlik çalışmaları da bu gereksinimlerden hareketle, bir firmanın ve yöneticisinin değerlerini uyumlaştıran bir liderlik tarzı için gerçekleştirilmiştir (Fernandez ve Hogan, 2002, s. 26). Yani değerlere dayalı liderlik, bir liderin yöneticilik faaliyetlerini yaparken, kararlar alırken değerleri, inançları, tutumları, normları ne kadar dikkate alındığıyla ilgilidir.

\section{Dönüşümsel Liderlik}

James McGregor Burns 1978 yılında yazdığı ve sosyolojik bir çalışma olan "dönüşümsel liderlik" adlı çalışmasını kavram olarak geliştirmiştir. Burns'e göre dönüşümcü liderler işgörenlerini adalet ve eşitlik gibi hususlarda yüksek düzeyde motivasyon sağlayan bireyler olarak görmektedir. Bass tarafından geliştirilen dönüşümcü liderlikse basit alışveriş, değiş-tokuş metotlarının dışına çkılmakta alternatif düşünce sistemleri geliştirilmektedir. Liderin amacı işgörenlerin tutumlarında farklılık yaratmak, ortak bir vizyon oluşturmak, örgütsel amaçlara ve hedeflere yönelik bağlllık sağlamak, kişisel gelişimi olanaklı kılan bir örgüt iklimi oluşturmaktır (Bakan ve ark., 2015, s. 203). Bass tarafından geliştirilen liderlik yaklaşımı firmaların geleneksel yönetimden modern yönetime geçişte sürecin yürütülmesini sağlayan bireylerin yetiştirilmesidir.

Dönüşümsel liderlik, izleyenlere, firmanın mükemmel performansa ulaşmasını sağlayan daha yüksek heves, özveri, bağlılık ve ekstra gayret gösterimlerine ilham verme hususunda güçlü bir potansiyel ortaya koymaktadır. İşgörenlerin güven, sadakat, adalet ve öz-yeterlik, özgüven ve öz-değer artışlarına dayanmaktadır (Rua ve Araujo, 2016, s. 46). Dönüşümcü liderlik genellikle en etkili liderlik biçimi olarak belirtilmektedir. Dönüşümsel liderlik tarzı, ortak değerlere ve gereksinimlere vurgu yapan çok boyutlu bir liderlik tarzını ifade etmektedir. İzleyenlerin kişisel gereksinim ve değerlerinden çok 
ortak değerlere ve gereksinimlere dayanmaktadır ve izleyenlerin beklentilerinin dışında performans sergilemelerini sağlamaktadır. Değişime ve dönüşüme odaklanması ile dönüşümcü liderlik takipçilerin duygularına dokunmaktadır (Güllüce ve ark., 2016, s. 264). Dönüşümsel liderler, işgörenlerin motivasyonların arttırma ve geleceğe yönelik bir vizyon oluşturarak takipçilerini bu vizyona inandırma beceri, kapasite ve enerjisine sahiptir (Gül ve Şahin, 2011, s. 242).

Dönüşümsel liderlik, örgüt üyelerini değiştirme ve dönüştürme sürecidir. $\mathrm{Bu}$ liderlik tarzını uygulayan liderler izleyenlerini becerilerinin ötesinde yapabildiklerinden veya istediklerinden daha fazlasını yapmaya ve çalışmaya teşvik etmektedir. Dönüşümcü liderler adanmış ve doyumlu izleyenlere sahip olma eğilimindedir. İşgörenlerini yetkilendirir, gereksinimlerine ve gelişimlerine dikkat etmektedir, kendi liderlik potansiyellerini arttırmalarına yardımcı olmaktadır (Mujkic ve ark., 2014, s. 259).

\section{Otantik Liderlik}

Yapılan pozitif örgütsel davranış alanındaki araştırmalarda, geleneksel liderlik yaklaşımlarının yerine işgörenlerin pozitif taraflarına önem verilmesi gerektiğini vurgulayan pozitif liderlik tarzlarına ağırlık verilmektedir (Ilies, Morgeson ve Nahrgang, 2005'den aktaran Yeşiltaş, Kanten ve Sormaz, 2013, s. 334). Pozitif liderlik tarzlarından bir tanesi olan otantik liderlik, küresel rekabet koşullarında örgütlerin gereksinimlerine cevap verebilecek, iş yaşamında güven sağlayabilecek, pozitif, etik ve şeffaf davranışlar sergileyebilecek, temeli pozitif örgütsel davranışlara dayanan bir liderlik tarzıdır (Wang ve ark., 2014, s. 5). Otantik liderler geleneksel yönetim anlayışını modern yönetim anlayışı ile harmanlayarak daha pozitif bir yönetim anlayışını kabul etmektedir.

Kesken ve Ayyıldız (2008, s. 736-738)'a göre; bu tarz liderler kendi karakterine, öz değerlerine, duygularına ve tercihlerine bağlı olduğu oranda otantiktir. Otantik liderler örgütü belirlenmiş olan hedefleri gerçekleştirmede birçok özelliği barındırır. Bu özelliklerden bazıları aşağıdadır: Akıl ile beraber tutku, merhamet gibi davranışları kullanır. İzleyicilerini güçlendirir ve onlara hizmet etmek isterler. Öncelikle kendilerine karşı dürüsttür ve başkalarının ne dediğinkinden ziyade kendi doğrularını dikkate alır ve doğrularından vazgeçmezler. Otantik lider doğuştan getirilen bir özellik değildir ancak 
otantik liderler bu özelliklerini devamlı geliştirilebilir. Otantik liderler başkalarını taklit etmez. Otantik liderler sosyal menfaatleri, kişisel menfaatlerinin üzerinde tutar.

Otantik liderlik yeni gelişen liderlik kuramlarından birisi olup, liderlik literatürü içerisinde geniş yer almış bir kavramdır. Otantik liderlik, liderlik kuramı içerisinde halen emekleme sürecindedir (Billsberry ve North-Samardzic, 2016, s. 2). Firmalar otantik liderler sayesinde rekabetçi pazar koşullarında sürdürülebilirliği sağlamaktadır (Zubair ve Kamal, 2015, s. 152). Otantik liderler firma içerisinde lider üye etkileşimini de artırmaktadır (Hirst ve ark., 2016, s. 486). Otantik liderler; kendilerini izleyenlerine açarak ve gizlilerini azaltarak onlarla etkin iş ilişkileri kurmaktadır (Xiong ve Fang, 2014, s. 923). Dijital dünyada çalışanları elinde tutmak isteyen firmalar, onları duygusal ve ahlaki yönden örgüte bağlamayı amaçladığı göz önünde bulundurulduğunda bir sonraki bölümde bu eylemi nasıl ve ne şekilde gerçekleştirdiği ele alınacaktır.

\section{Motivasyon Kavramı}

Rekabet koşullarının zorlaşması organizasyonları daha kaliteli ürün ve hizmeti daha az maliyetle üretmeleri hususunda mecbur bırakmaktadır. $\mathrm{Bu}$ mecburiyet ise iş gücünün verimli çalışması için gerekli olan motivasyonun artması konusunda gün geçtikçe daha fazla hissettirmektedir. Bir çalışanın motive edilmesi bireysel ve örgütsel yönden incelenmesi gereken bir konudur. Örgütsel yönden bakıldığında, "çalışanın motive edilmesi; çalışanın ihtiyaçlarının temin edilerek örgüt tarafından tayin edilmiş amaçlar doğrultusunda faaliyette bulunmasının sağlanması" olarak ifade edilirken, kişi yönünden ise "kişilerin belirli bir amacı gerçekleştirmek amacıyla kendi istek ve arzuları ile davranmaları ve çaba içinde olmaları" şeklinde tanımlanmaktadır (Turhan ve Çetinsöz, 2019, s. 272).

Motivasyon, bir kişiyi faaliyette bulunmaya teşvik eden içsel faktörler ile faaliyete iten dışsal faktörleri içermektedir. Bu nedenle motivasyona yönelik teorik bilgilerin bir kısmı motivasyonun varolmasını ortaya çıkaran dışsal ve içsel faktörlerden bahsedilmektedir (Herzberg, 1966, Alderfer, 1972; McClelland, 1961 Maslow, 1943), diğer kısmı da bu faktörlerin oluşmasının sürecini anlatmaktadır (Bandura, 1977; Adams, 1963; Porter \& Lawler, 1968; Locke, 1968; Vroom, 1964). Bu teoriler doğrultusunda yapılan ampirik çalışmaların 
işçi motivasyonu ile ilgili önemli etkileri olmuştur. Fakat, Gallup'un yaptığı çalışmanın sonuçlarına göre uygulamada faydalı olacak işgören motivasyonuyla ilgili çalışmaların alan yazında az olduğu görülmektedir (Tağ ve Çetinkaya, 2019, s. 859).

\section{İş Motivasyonunun Anlamı ve Önemi}

İş motivasyonu, örgütün hedeflerine ulaşabilmesi yönünde çalışanın çaba gösterme ve devamlılığın sağlama hususunda ne derece istekli olduğu ile ilgilidir. Pinder (2014, s. 11) iş motivasyonunu "iş ile ilgili davranışı başlatma, yönüne, şekline, süresine ve yoğunluğa karar verme konusunda çalışanın içsel motivasyonunun yanında dış çevre faktörlerinin teşvik ettiği bir dizi enerjik güçler" olarak tanımlamıştır. Tanımda bahsedilen enerjik güçler; ihtiyaçlar, güdüler, itici faktörler ve dışsal faktörlerin çok bileşenli yapısını belirtmektedir (Köse, 2019, s. 135).

Örgütsel ve bireysel hedeflere ulaşmak adına işgörenlerin motive edilmesi konusu önem taşımaktadır. Motivasyon kavramını, işgörenin belirli hedef ve ihtiyaçların gerçekleştirmek için faaliyette bulunma, hedef belirleme ve sonuca ulaşıncaya değin gerekli çabayı devam ettirme süreci olarak tanımlanabilir. Motivasyon sürecinde dişsal ve içsel unsurlar etkili olmaktadır. İş hayatında motivasyonun asıl amacı, işgörenlerin başarı seviyelerini yükselterek verimlilik ve etkinlik çerçevesinde örgütsel hedeflere ulaşılmasını sağlamaktır. Yöneticinin de başarılı olma ihtimali büyük oranla örgütünü, örgütsel hedefler doğrultusunda motive edebilmesiyle bağlantılıdır. Hedeflenen başarı seviyesine gelebilmek için iş görenler maddi ve manevi motivasyon araçları ile desteklenmelidir (Köse, 2019, s.132).

İşgörenler sorumlu oldukları görevleri yapmaya motive olmadıkça, örgüt içinde verimlilik ve etkenlik sağlanması söz konusu olmaz. Örgüt içinde etkin bir motivasyon, verilen emirlerin kabulünü kolaylaştırdığı gibi, görevlerin daha hızlı ve verimli olarak yerine getirilmesine de destek olur. Bir kişinin fiziki varlığı, emeği ve zamanı finansal olarak satın alınabilir; ancak onun yaratıcllğı, sadakati, girişimci ruhu, fiziken, zihnen ve ruhen kendisini örgütün hedefleri doğrultusunda kullanılması parayla satın alınamaz bir durumdur. Bunlar yalnızca örgüt içinde iyi bir motivasyonun varlığı ve teşvikiyle sağlanabilir (Güzel, 2010, s. 3416). 


\section{Motivasyon Teorilerinin Başlıca Katkıları}

Motivasyon, bir bireyi belirli bir amaç doğrultusunda faaliyete geçiren güç veya bir ya da birden fazla bireyi belirli bir doğrultu istikametinde devamlı olarak harekete geçirme çabası olarak ifade edilebilir. Organizasyonun sahip olduğu kısıtlı kaynaklarla sınırsız ihtiyaçlar karşılanmaya çalışıııken, sınırsız olan bütün ihtiyaçların karşılanmasına dair mal ve hizmet sunmak basit bir faaliyet olmayıp bazı teknik ve idari analizlerden geçmesi gereken bir süreçtir (Keser, 2012, s. 96). Motivasyon, bir kişiyi faaliyette bulunmaya teşvik eden içsel faktörler ile faaliyete iten dişsal faktörleri içermektedir. Bu nedenle motivasyona yönelik teorik bilgilerin bir kısmı motivasyonun varolmasını ortaya çıkaran dişsal ve içsel faktörlerden bahsedilmektedir (Herzberg, 1966, Alderfer, 1972; McClelland, 1961 Maslow, 1943), diğer kısmı da bu faktörlerin oluşmasının sürecini anlatmaktadır (Bandura, 1977; Adams, 1963; Porter ve Lawler, 1968; Locke, 1968; Vroom, 1964). Bu teoriler doğrultusunda yapılan ampirik çalışmaların işçi motivasyonu ile ilgili önemli etkileri olmuştur. Fakat Gallup'un yaptığı çalışmanın sonuçlarına göre uygulamada faydalı olacak işgören motivasyonuyla ilgili çalışmaların alan yazında az olduğu görülmektedir (Tağ ve Çetinkaya, 2019, s. 859).

İhtiyaçlar hiyerarşisi teorisinin başlıca katkısı, kişiler belli bir sıralama gösteren ihtiyaçlara sahiptir ve onları tatmin edecek şekilde davranmaktadır. Çift faktör teorisinde ihtiyaçlar temel motivasyon faktörüdür ancak bazı faktörler motive etmez, motivasyonun varlığı için gereklidir. Davranışsal şartlandırma teorisinde, belirli ödül ve ceza uygulaması ile aruz edilen davranışların kuvvetlendirilebileceği gibi arzu edilmeyen davranışlarında zayıflatılabileceğidir. Eşitlik teorisinin başlıca katkıları, bireylerin çaba sarfettikleriyle sonuçta elde ettiklerinin karşılaştırılabilmesidir. Hedef teorisinde, ulaşılmak istenen hedeflerin ulaşılabilirliği ile çalışanların performansları ve motivasyonları arasında ilişki olmasıdır. Başarma ihtiyacı teorisinde de bir çalışanın performansı sahip olduğu başarı ihtiyacıyla açıklanabilmektedir. Motivasyon teorilerini temel alarak geliştirilen sosyal motivasyon, farklı ihtiyaçları olan çalışanların ayrı ayrı tatmin etmek yerine üyesi olduğu örgütün ihtiyaçlarını karşılayarak, örgüt hedefleriyle özdeşleştirilebileceğini savunmuştur. Sonuç olarak her teori örgütün verimlilik ve etkinliğini arttırabilmek için personeli en üst düzeyde amaçlara motive etmenin yollarını aramaktadır, kendi bakış açısından çözüm yolları bulmaktadır. Yönetici başarıyı yakalayabilmek 
için işgörenleri motive eden faktörleri iyi tahlil etmeli, hedefler doğrultusunda davranmalıdır.

\section{Yöntem}

$\mathrm{Bu}$ çalışma ile dijitalleşme ortamının firmalara getirdiği avantajlar ve zorluklar, dijitalleşme ile değişen liderlik prensipleri ve bunların çalışan motivasyonuna nasıl yansıdığı yapılan anketlerle incelenerek ele alınmıştır. Bu araştırmada; X firmasının (Firma A, Firma B, Firma C) çalışanlarıyla anket gerçekleştirilmiştir. Bu bağlamda çalışanlara, bağlı bulundukları firmanın hangi departmanında çalıştıkları ile doğum yıl aralığı, cinsiyeti vb. profil sorularına yanıt alınmıştır. Profil sorularının yanında katılımcılara Liderlik ve Motivasyon kapsamlı toplam 59 ifade yöneltilerek ölçülmüştür. İfadelerin başlıklara göre dağılımı şu şekildedir; liderlik ölçeği 33 ifade (5'li likert ölçek), motivasyon ölçeği 26 ifade (5'li likert ölçek)'dir.

Çalışma kapsamında Firma B'nin İstanbul'da yer alan genel müdürlük, pazarlama ve satış fonksiyonları ile üretim tesisleri, Firma C'nin Aksaray'da yer alan üretim tesislerinde ve ayrıca Firma A'nın Almanya ofisinde ayrı ayrı gerçekleştirilecek görüşme ve anketlerde şu konularda bulgular elde edilmeye çalışlacaktır: Şirkette sergilenen liderlik davranışları ile motivasyon arasında nasıl bir ilişki vardır? X, Y ve Z jenerasyonları arasında motivasyon ve beklenen liderlik düzeyleri açısından fark bulunmakta mıdır? Liderlik tarzları kişilerin motivasyon nasıl etkilemektedir. Tüm bu değişkenler şirketin farklı lokasyonlarında farklılık göstermekte midir?

Verilerin analizinde SPSS 15.00 İstatistik Paket Programı kullanılmıştır. Ordinal ve Nominal ölçekli soruların çözümlemesinde tanımlayıcı istatistikler (Descriptive Statistics), likert ölçekli soruların analizinde ise Faktör analizi kullanılmıştır. Faktörlerin ve değişkenlerin güvenilirliğini ölçmek için yapılan Güvenilirlik Analizi'nde (Reliability Analysis) ise Cronbach Alpha değeri kullanılarak yorumlanmıştır. Hipotezler testi için ise Basit Regresyon analizi kullanılmıştır.

\section{Örneklem}

Araştırma tek firma üzerinden yürütülmüş ve aynı firmanın farklı lokasyonlarındaki çalışanlar üzerinden çalışılmıştır. Bu çalışmada X firmasına bağlı 
toplam 150 çalışan ile görüşmeler gerçekleştirilmiştir. Yapılan tüm analizler, her bir görüşmeci aynı firmayı temsil ettiğinden, tek veri olarak değerlendirilmek üzere toplam 150 baz üzerinden gerçekleştirilmiştir. Yapılan ölçeklemenin faktör ve güvenilirlik analizleri de 150 kişi üzerinden yapılmıştır.

\section{Bulgular}

\section{Demografik bulgular}

Anketi eksiksiz dolduran 150 çalışanın tanımlayıcı istatistikleri şöyledir. Katılımcıların \%90,7'si (n=136) Türkiye, \%18,6'sı (n=31) Almanya bölgesine bağlı çalışanlardır. Lokasyonların dağılımına bakıldığında çalışanların \%58,7'si Hadımköy, \%24,7'si Hoşdere, \%11,3’ü Aksaray ve \%5,3'ü ise Almanya'da çalışmaktadır. Ayrıca ülke ve lokasyon dağılımı çizelge 8' de gösterilmiştir. Katılımcıların \%35,3'ü kadın, \%64,7'si erkeklerden oluşurken, en yüksek mevcudu $\% 52,7$ ile Y jenerasyonu paylaşmaktadır. Örneklemdeki X jenerasyonun oranı $\% 8,0 \mathrm{Z}$ jenerasyonunun oranı ise $\% 39,3$ 'dür. Ankete katılanların bağlı bulundukları departmanlar firmanın yapısına bağlı olarak oldukça geniş bir dağılım göstermiştir.

Araştırmaya katılan görüşmecilerin \%52'si Memur, \%27,3’ü E4, \%11,3’ü E5, \%5,3'ü E3, \%1,3'ü E2, \%1,3'ü Müdür Yardımcisı ve \%1,3’ü Uzman düzeyinde çalışanlardan oluşmaktadır. Çalışanların kıdemlerine bakıldığında uzun soluklu bir çalışma hayatı olduğu söylenebilir. Görüşmecilerin \%80'inin üzerinde 5 yıl ve daha uzun süredir çalıştıkları, \%62'sinin ise 10 yıl ve üzeri süredir burada çalıştıkları gözlenmiştir. PEP Stajyerinden geçenlerin oranı $\% 15,6$ iken, stajyerlikten geçmeyenlerin oranı $\% 84,4$ 'dür. Görüşmecilerin toplam kıdemine bakıldığında ortalama kıdem yılı 11 yıldır. 10 yıl ve üzeri kıdeme sahip çalışanların oranı \%76'dır. 5-10 yıl arası çalışma hayatı olanların orası ise $\% 19,3^{\prime}$ dür.

\section{Jenerasyona göre farklilılarn incelenmesi}

Katılımcılara yöneltilen doğum yıl aralığı grupları üzerinden oluşturulan X,Y ve $\mathrm{Z}$ jenerasyonlarına göre liderlik, rekabet, motivasyon ve bağlllık ifadelerinde anlamlı bir farklılık olup olmadığı incelenecektir.

X Jenerasyonu $\rightarrow$ 1965-1979 yılı doğumlu 
Y Jenerasyonu $\rightarrow$ 1980-1999 yılı doğumlu

Z Jenerasyonu $\rightarrow$ 2000-.... yılı doğumlu

Tablo 1. Jenerasyona Göre Ana Değişkenler Arasındaki Farklılıklar

\begin{tabular}{llll}
\hline & X Jenerasyonu & Y Jenerasyonu & Z Jenerasyonu \\
\hline Baz & (A) & (B) & (C) \\
\hline Liderlik & $\mathbf{1 2}$ & $\mathbf{7 9}$ & $\mathbf{5 9}$ \\
\hline Motivasyon & 3,87 & 3,72 & 3,61 \\
\hline
\end{tabular}

Tablo 1'de sütunda jenerasyonlar, satırda ise genel ölçüm başlıkları bulunmaktadır. Tablonun içindeki rakamlar her bir ölçüm değişkeni için hesaplanan ortalama puanlardan (Mean) oluşmaktadır.

Tablo 1'de Baz olarak görünen satır, her bir jenerasyonun ana datada kaç örneklemle temsil edildiğini gösterirken, Jenerasyonların hemen altındaki A, $\mathrm{B}, \mathrm{C}$ harfleri ise kırılım değişkenlerini temsil eden basit harflerdir. Bu harflerle hangi grubun hangi gruba göre daha yüksek ortalamaya sahip olduğunun hem okunması hem de aktarılması daha kolay olmaktadır.

Sonuçlara göre motivasyon puanlarında jenerasyona göre anlamlı farklılık vardır. X Jenerasyonunun ortalamasının $(4,13)$ diğer gruplara göre yüksek olduğu görülürken, $Z$ Jenerasyonuna $(C)$ göre bu fark $\% 95$ güven düzeyinde anlamlı bir farklılıktır.

\section{Pearson Korelasyon analizine ilişkin bulgular}

Korelasyon analizi iki veya daha fazla değişken arasında bir ilişki olup olmadığını, şayet bir ilişki varsa bu ilişkinin şiddetini ve yönünü ortaya koyan bir istatistiki analizdir. Korelasyon katsayısı üzerinden ölçülür. Korelasyon katsayısı $-1<\mathrm{r}<+1$ arasında değişmekle birlikte, sıfıra yaklaştıkça ilişki zayıflar, $1^{\prime} \mathrm{e}$ yaklaştıkça ilişki kuvvetlenir. Korelasyon katsayısının işareti ise ilişkinin yönünü gösterir. (-) ters yönlü ilişkiyi, (+) ise doğrusal bir ilişki olduğunu gösterir. Korelasyon analizleri birden fazla bakış açısıyla incelenmiştir. Tablo 2'deki korelasyon tablosu; Faktör analizi sonrasında oluşan 20 faktör boyutunun birbirleriyle ilişkisini görmek amaçlı gerçekleştirilmiştir. Bahse konu 20 faktör boyutu, faktörleştiği değişkenler üzerinden ortalama alınarak hesaplanmıştır. Her bir ölçüm toplam 150 kişi üzerinden hesaplanmıştır. 
Tablo 2. Pearson Korelasyon Analizi

\begin{tabular}{lllll}
\hline & Takdir ve Ödüllendirme & Yetkinlik & Fiziksel Koşullar & Motivasyon \\
\hline Değişim Odaklı Liderlik & 0,651 & $0,531^{* *}$ & $0,32^{* *}$ & $0,357^{* *}$ \\
\hline İlişki Odaklı Liderlik & $0,639^{* *}$ & $0,431^{* *}$ & $0,266^{* *}$ & $0,263^{* *}$ \\
\hline Görev Odaklı Liderlik & $0,561^{* *}$ & $0,352^{* *}$ & $0,332^{* *}$ & $0,211^{* *}$ \\
\hline$* p \leq 0,05 * * p \leq 0,01$ & & & &
\end{tabular}

Tablo 2'de faktör sonrası oluşan boyutların korelasyon katsayıları belirtilmiştir. Tabloda her bir faktör boyutu olan değişken ortalamalarının birbirleriyle ilişkisi gözlenmiştir.

Tablo 3. Ana Değişkenler ile Faktör Boyutları Arasındaki Pearson Korelasyon Analizi

\begin{tabular}{lll}
\hline & Liderlik Tarzı & Motivasyon \\
\hline Değişim Odaklı Liderlik & $\left.0,976^{(* *}\right)$ & $0,672\left(^{* *}\right)$ \\
\hline İişki Odaklı Liderlik & $\left.0,891^{(* *}\right)$ & $0,604\left(^{* *}\right)$ \\
\hline Görev Odaklı Liderlik & $\left.0,817^{(* *}\right)$ & $\left.0,5344^{* *}\right)$ \\
\hline Takdir ve Ödüllendirme & $\left.0,681^{(* *}\right)$ & $0,905\left(^{* *}\right)$ \\
\hline Yetkinlik & $\left.0,514^{(* *}\right)$ & $0,832\left(^{* *}\right)$ \\
\hline Fiziksel Koşullar & $\left.0,334^{(* *}\right)$ & $0,503\left(^{* *}\right)$ \\
\hline Motivasyon & $\left.0,334^{(* *}\right)$ & $0,639\left(^{* *}\right)$ \\
\hline
\end{tabular}

$* p \leq 0,05 * * p \leq 0,01$

Tablo 3'de ana değişkenler ile faktör boyutlarına ait ortalamaların birbirleriyle korelasyonu incelenmiştir. Tabloya göre tüm değişkenlerle (Liderlik Tarzı ve Motivasyon) $p<0,01$ düzeyinde anlamlı bir ilişkiye sahip olan boyutlar aşağıdaki gibidir;

- Değişim Odaklı Liderlik

- Takdir ve Ödüllendirme

- Motivasyon

İlişki Odaklı Liderlik, Görev Odaklı Liderlik, Takdir ve Ödüllendirme, Yetkinlik, Fiziksel Koşullar ve Motivasyon boyutları ile Liderlik Tarzı ve Motivasyon değişkenleri $\mathrm{p}<0,01$ düzeyinde anlamlı bir ilişkiye sahiptir.

Aslında genel olarak Tablo 3'de değişkenler ile değişkenlerden doğan boyutlar aralarındaki ilişki bakımından incelenmiş oldu. Değişim Odaklı Liderlik, İlişki Odaklı Liderlik ve Görev Odaklı Liderlik Liderlik değişkeninin altında; Takdir ve Ödüllendirme, Yetkinlik, Fiziksel Koşullar ve Motivasyon Motivasyon altında faktörleşmişti. Korelasyon analizi ile değişkenlerin sadece kendilerine ait boyutları ile arasındaki ilişki değil, bununla birlikte birbirleri arasındaki ilişki de çözümlenmiştir. 
Boyutlar hem birbirleriyle hem de değişkenlerle çeşitli düzeylerde ilişkidedir. Bu ilişkilerin anlamlılığı yukarıda açıklanmış olup ilişkinin şiddeti hakkında fikir sahibi olmak için tablodaki r değerleri incelenmelidir.

Tablo 4. Ana Değişkenlerin Birbiriyle Kendi İçindeki Korelasyonu

\begin{tabular}{lllll}
\hline & Liderlik & Rekabet & Motivasyon & Bağlılık \\
\hline Liderlik & 1 & $0,513\left({ }^{* *}\right)$ & $\left.0,6699^{* *}\right)$ & $\left.0,350{ }^{(* *}\right)$ \\
\hline Motivasyon & $\left.0,6699^{* *}\right)$ & $0,560\left(^{* *}\right)$ & 1 & $0,452\left(^{* *}\right)$ \\
\hline$* p \leq 0,05 * * p \leq 0,01$ & & &
\end{tabular}

Tablo 4'de ana değişkenlerin birbirleriyle kendi içlerindeki korelasyonu çift yönlü olarak incelenmiştir.

Ana değişkenlerin birbirleriyle ilişkisi incelendiğinde en yüksek ilişkinin r=0,669 ile Liderlik ile Motivasyon arasında olduğu görülmektedir.

\section{Hipotezlere ilişkin bulgular}

Aşağıda yapılan Regresyon Analizinin bağımlı, bağımsız değişkenlerin, beta katsayılarının, düzeltilmiş $\mathrm{R}^{2}$ lerin, $\mathrm{F}$ değerlerinin, sonuç ve hipotezlerin gösterildiği tablo yer almaktadır.

Tablo 5. Araştırma Hipotezlerinin Sonuçlar

\begin{tabular}{|c|c|c|c|c|c|c|c|}
\hline $\begin{array}{l}\text { Bağımsız } \\
\text { Değișkenler }\end{array}$ & $\begin{array}{l}\text { Bağımlı } \\
\text { Değișkenler }\end{array}$ & B & $p$ & $\mathbf{R}^{2}$ & F & Sonuç & Hipotezler \\
\hline $\begin{array}{l}\text { Değişim } \\
\text { Odaklı } \\
\text { Liderlik }\end{array}$ & \multirow{3}{*}{ Motivasyon } & 0,324 & 0,000 & \multirow{3}{*}{0,032} & \multirow{3}{*}{42,292} & Kabul & $\begin{array}{l}\text { H4a: Değişim Odaklı Li- } \\
\text { derlik Motivasyonu pozi- } \\
\text { tif yönde etkiler }\end{array}$ \\
\hline $\begin{array}{l}\text { İlişki } \\
\text { Odaklı } \\
\text { Liderlik }\end{array}$ & & 0,105 & 0,141 & & & Red & $\begin{array}{l}\text { H4b: İlişki Odaklı Liderlik } \\
\text { Motivasyonu pozitif yönde } \\
\text { etkiler }\end{array}$ \\
\hline $\begin{array}{l}\text { Görev } \\
\text { Odaklı } \\
\text { Liderlik }\end{array}$ & & 0,064 & 0,398 & & & Red & $\begin{array}{l}\text { H4c: Görev Odaklı Liderlik } \\
\text { Motivasyonu pozitif yönde } \\
\text { etkiler }\end{array}$ \\
\hline $\begin{array}{l}\text { Takdir } \\
\text { ve Ödüllen- } \\
\text { dirme }\end{array}$ & \multirow{4}{*}{ Liderlik } & 0,548 & 0,000 & \multirow{4}{*}{0,482} & \multirow{4}{*}{35,64} & Kabul & $\begin{array}{l}\text { H10a: Takdir ve Ödüllen- } \\
\text { dirme Liderliği pozitif } \\
\text { yönde etkiler }\end{array}$ \\
\hline Yetkinlik & & 0,195 & 0,031 & & & Kabul & $\begin{array}{l}\text { H10b: Yetkinlik Liderliği } \\
\text { pozitif yönde etkiler }\end{array}$ \\
\hline $\begin{array}{l}\text { Fiziksel } \\
\text { Koşullar }\end{array}$ & & 0,114 & 0,085 & & & Red & $\begin{array}{l}\text { H10c: Fiziksel Koşullar Li- } \\
\text { derliği pozitif yönde etkiler }\end{array}$ \\
\hline Motivasyon & & $-0,061$ & 0,480 & & & Red & $\begin{array}{l}\text { H10d: Motivasyon Lider- } \\
\text { liği pozitif yönde etkiler }\end{array}$ \\
\hline
\end{tabular}


Yukarıdaki tabloda değişim odaklı liderliğin motivasyonu, takdir ve ödüllendirme ve yetkinliğin ise liderliği pozitif etkilediği görülmektedir.

\section{Sonuç ve Öneriler}

Günümüzde giderek daha çok artan rekabet, hız ve dijitalleşme tüm şirketleri potansiyeli yüksek çalışanları örgütlerine çekme ve özellikle değişen jenerasyon dinamikleri ile onları örgütte yüksek performansla çalışır halde tutma konusunda zorlamaktadır. Örgütler hedefleri doğrultusunda yüksek karlılıkta çalışarak pay sahiplerine ve paydaşlarına sürdürülebilir katkı sağlamakla yükümlüdür. Bu bağlamda motivasyon ve liderlik modelleri şirketin amaç ve hedeflerine direkt etkili olarak günümüzün iş dünyasında son derece önemli hale gelmiştir. İşletmelerin başarısı için sahip olduğu finansal ve fiziksel olanaklarının yanısıra çalışanlarının yetenekleri, yöneticilerinin liderlik şekilleri de büyük önem taşır. Bu bağlamda çalışmamızda hem şirket içi değişkenlere bakılmış hem de çalışanların motivasyonları değerlendirilmiştir. Araştırma birbirlerini etkileyen değişkenlere baktığımızda; değişim odaklı liderlik boyutunun motivasyonu pozitif yönde etkilediği görülmüştür. Motivasyon boyutlarının etkileme oran incelendiğinde ise; takdir ve ödüllendirme ile yetkinliğin liderliği pozitif yönde etkilediği sonucu alınmıştır.

$\mathrm{Bu}$ araştırmada görev odaklı ve ilişki odaklı liderlik davranışları değişim odaklı liderlik davranışlarına göre daha fazla çıkmıştır. Davranışsal liderlik yaklaşımlarından Ohio Üniversitesi Liderlik Yaklaşımı bu araştırma sonucunu desteklemektedir. Kişiyi dikkate alma ve insiyatif kullanma davranışları görev ve ilişki odaklı liderlik özelliklerini ifade etmektedir.

Araştırmamıza konu olan şirketlerde her ne kadar farklı coğrafi lokasyonlar bulunsa da aynı şirketin kültürel özelliklerini taşıdıkları ancak bunun jenerasyonlar nezdinde farklılaştığ1 söylenebilir. Bu yönü ile günümüzün dijitalleşen ortamında şirketler için çok önemli bulunan genç ve yetenekli jenerasyonların örgütlere çekilebilmesi ve örgütte tutundurulabilmesi için örgütlerin son derece dikkatli olması gerekiyor. Zira yıllardır başarılı şekilde faaliyetinde bulunan bu gibi örgütlerde farklı jenerasyonların bir arada uyum içerisinde çalışması son derece önemlidir. Ancak motivasyon boyutunda jenerasyonlar arası farklı anlayış ve beklentiler dikkatli şekilde ele alınarak uygu- 
lamalar hayata geçirilmelidir. Örgütün yüksek karlılıkta çalışarak pay sahiplerine ve paydaşlarına sürdürülebilir katkı sağlamaya devam etmesi, rakiplerine fark yaratan hamlelerde bulunabilmesi, gelecek için sağlam adımlar atarak hızla değişen dünya dinamiklerine çevik şekilde uyumlanabilmesi ancak tüm bu farklılıkları tespit ederek ve uygun hamleleri hayata geçirmesi ile mümkün olabilecektir. Bu anlamda örgütte yürütülebilecek odak grup çalışmaları ile örgütün geleceği adına son derece faydalı öngörü ve tespitlerde bulunularak geleceğe hazırlanması mümkün kılınabilinir.

$\mathrm{Bu}$ araştırma sonucu ile Endüstri 4.0 döneminde firmaların yeni liderlik tarzlarının, çalışanların motivasyonlarının belirlenmesi hem işletme literatürüne hem de faaliyet gösteren firmalara yol gösterici olacağ 1 ve rekabet avantajı sağlamada katkı sağlayacağı düşünülmektedir. Dijital dünyada firmalar rekabet avantajı sağlayabilmek için yeni teknolojilerden faydalanmalı ve yönetim tarzların da değiştirmelidir. Bu sebeple firmalara verilebilecek önerilerden en önemlisi değişim odaklı liderlik anlayışı ile hareket etmeleridir. Firmaların başarılı olmasında etkisi olan insan kaynağının motivasyonunu da sağlaması önemlidir. Bu yüzden motivasyon aracı olarak firmalar objektif performans değerlendirme sistemini kullanmalı ve başarılı çalışmalar gerçekleştiren çalışanlarına terfi olanakları sunmalıdır. 


\title{
EXTENDED ABSTRACT
}

\section{A Comparative Research on New Leadership and Motivation Models in Digitalized Companies}

\author{
Başak Demiryumruk Dikici \\ İstanbul Aydın University
}

Globalization, which is becoming more and more important today, affects individuals as well as businesses. With the changing world, new economy, and especially digitalization, companies are investing in different countries, establishing sales-marketing networks in different geographic areas and even building production facilities in different countries. These global enterprises operating in different locations try to keep their success rates at the same level in other locations in their home country. Companies try to show the same character at every point as a global brand by keeping the leadership models, employee motivation levels and even employee turnover rates at a certain level.

In today's intense competitive environment, the purpose of their companies is not only to produce or sell, but also to attract high-potential employees to their organizations, to keep them in the organization in the most efficient way, to work in the highest efficiency and profitability in line with the goals of the organization and to contribute to the shareholders and stakeholders in a sustainable manner. has been to present. For this reason, the motivation and leadership models, which have been determined to have a direct effect on the company's goals and objectives, maintain and continue to stand out. The global markets and new production systems, which are constantly in motion, are entering the challenges of the increasing competition environment, and the world is constantly witnessing innovations in a total transformation. Digitalization, which is constantly on the business agenda, is one of the biggest grounds of these new world formations. As we know, in the late 18th century, mechanical production systems using water and steam power (Industry 1.0) left its place to electrical power and its mass production (Industry 2.0) when it entered the 20th century. In the 1970s, a more automated production process was initiated with the development of information technologies (Industry 3.0). 
The 21st century brought a completely different industrial revolution, where production based on cyber-physical systems can be made, objects can be communicated and managed over the internet, and autonomous interaction and virtualization can be adapted to almost any industry. In this new period called Industry 4.0, technology is radically changing the traditional working systems in daily life and business life. Many studies are carried out in companies to keep up with changing technology and working systems. Digitalization, which is the biggest part of this transformation, increases the importance of transferring hand-collected data and professional processes to computers or digital media. Thanks to the functional power of computers, processes are accelerating; Access to all data and resource management becomes easier. All this transformation allows for companies to have completely different initiatives not only in production and other services but also in leadership and employee motivation. Leadership and employee motivation in companies experiencing this change have been extensively discussed in this study.

Nowadays, increasing competition, speed and digitalization force all companies to attract high-potential employees to their organizations and to keep them working with high performance in the organization, especially with the changing generation dynamics. Organizations are obliged to make a sustainable contribution to their shareholders and stakeholders by working with high profitability in line with their goals. In this context, motivation and leadership models have become extremely important in today's business world, directly influencing the company's goals and objectives. In addition to the financial and physical possibilities for the success of the enterprises, the talents of the employees and the leadership styles of their managers are of great importance. In this context, in our study, both the internal variables were subjected and the motivations of the employees were evaluated. When we look at the variables that affect each other in the research; change-oriented leadership dimension has been shown to affect motivation positively. When the influence rate of motivation dimensions is examined; appraisal and rewarding and competence have been concluded that positively affect leadership.

In this research, task-oriented and relationship-oriented leadership behaviors were more common than change-oriented leadership behaviors. Ohio University Leadership Approach, one of the behavioral leadership 
approaches, supports this research result. Person-taking and initiative behaviors represent task- and relationship-oriented leadership characteristics.

Although there are different geographic locations in the companies that are the subject of our research, it can be said that they have the cultural characteristics of the same company, but this differs in terms of generations. With this aspect, organizations should be extremely careful in order to attract young and talented generations that are very important for companies in today's digital environment, and to be promoted in organizations. Because in such organizations that have been operating successfully for years, it is extremely important that different generations work together in harmony. However, practices should be put into practice by carefully considering different understandings and expectations between generations in terms of motivation. The organization continues to make sustainable contributions to its shareholders and stakeholders by working at high profitability, to make moves that make a difference to its competitors, to be able to adapt to the rapidly changing world dynamics by taking solid steps for the future, only by identifying all these differences and realizing appropriate moves. . In this sense, it can be made possible to prepare for the future by making highly useful foresights and determinations for the future of the organization with the focus group works that can be carried out in the organization.

As a result of this research, it is thought that determining the new liberty styles and motivation of the firms in Industry 4.0 period will contribute to both the business literature and the companies that operate and provide a competitive advantage. In the digital world, companies must take advantage of new technologies and change their management styles in order to gain competitive advantage. For this reason, the most important of the suggestions that can be given to companies is to act with a change-oriented leadership approach. It is also important to ensure the motivation of the human resource, which has an impact on the success of companies. Therefore, companies should use the objective performance evaluation system as a motivation tool and offer promotion opportunities to their employees who perform successful studies. 


\section{Kaynakça / References}

Bakan, İ., Erşahan, B., Büyükbeşe, T., Doğan, İ. F. ve Kefe, İ. (2015). Dönüşümcü ve etkileşimci liderlik ile öğretmenlerin tükenmişlik düzeyleri arasındaki ilişki. International Journal Of Economic and Administrative Studies, 1(14), 201-222.

Billsberry, J. ve North-Samardzic, A. (2016). Surfacing authentic leadership: Inspiration from after life. Journal Of Leadership Education, 15(2), 1-13.

Fernandez, J. ve Hogan, R. T. (2002). Values based leadership. The Journal for $Q u-$ ality and Participation, 25(4), 25-26.

Gül, H. ve Şahın, K. (2011). Bilgi toplumunda yeni bir liderlik yaklaşımı olarak transformasyonel liderlik ve kamu çalışanlarının transformasyonel liderlik algisı. Selçuk Üniversitesi Sosyal Bilimler Enstitüsü Dergisi, 25(1), 237239.

Güllüce, A. Ç., Kaygın, E., Kafadar, S. B. ve Atay, M. (2016). The relationship between transformational leadership and organizational commitment: A study on the bank employees. Journal of Service Science and Management, 9(1), 263-275.

Güzel, Ö. F. (2010). Turizm öğrencilerinin staj döneminde edindikleri motivasyonun herzberg teorisine göre değerlendirilmesine yönelik bir araştırma. Yaşar Üniversitesi Dergisi, 20(5), 3415-3429.

Hirst, G., Walumbwa, F., Aryee, S., Butarbutar, I. ve Chen, C. J. (2016). A multi level investigation of authentic leadership as an antecedent of helping behavior. J Bus Ethics, 139(1), 485-499.

Keser, A. (2012). Motivasyon: Çalı̧ma psikoloji (3. Baskı). Bursa: Ekin Yayınları.

Kesken, J. ve Ayyıldız, A. N. (2008). Liderlik yaklaşımlarında yeni perspektifler: pozitif ve otantik liderlik. Ege Akademik Bakış, 8(2), 729-754.

Köse, E. (2019). Çalışanların iş tatmini algıları ile iş motivasyonu düzeyleri arasındaki ilişkinin araştırılması. Bilecik Şeyh Edebali Üniversitesi Sosyal Bilimler Enstitüsü Dergisi, 4(1), 131-148.

Maier, T., Bombard, P., Gentile, M. ve Tavanti, M. (2015). Millennial generation perceptions of value-centered leadership. Journal of Human Resources in Hospitality \& Tourism, 1(14), 382-397.

Mujkıc, A., Sehıc, D., Rahımıc, Z. ve Jusıc, J. (2014). Transformational leadership and employee satisfaction. Econviews, God, 27(2), 259-270.

Özkan, M., Al, A. ve Yavuz, S. (Eylül 2018). Uluslararası politik ekonomi açısından dördüncü sanayi-endüstri devriminin etkileri ve Türkiye. Marmara Üniversitesi Sosyal Bilimler Dergisi, 6(2), 126-156. 
Rua, O. M. ve Araujo, J. C. (2016). Linking transformational leadership and organizational trust: Has organizational commitment a mediating effect on it. Cuadernos De Gestión, 16(1), 43-62.

Schwab, K. (2016). Dördüncü Sanayi Devrimi (Çev. Z. Dicleli). İstanbul: Optimist Yayıncilik.

Tağ, N. M. ve Çetinkaya, B. (2019). Öznel iyi oluş hali, başkasına güven ve iş motivasyonu arasındaki ilişki: Beklenti teorisi çerçevesinde çok düzeyli analiz. Uluslararası Yönetim İktisat ve İşletme Dergisi, 15(3), 857-884.

Tarıyan, Ö. (2018, Şubat 23). İnovasyon kültürünün ve teknolojinin çalışma hayatı üzerinde etkileri. The Deloitte Times, 1-76. https:/www2.deloitte.com/tr/tr/pages/about-deloitte/topics/the-deloitte-times-subat2018.html adresinden alınd.

Turhan, M. ve Çetinsöz, B. C. (2019). Duygusal zekâ ve motivasyon arasındaki ilişki: turizm programı öğrencileri üzerine bir araştırma. Elektronik Sosyal Bilimler Dergisi, 18(69), 268-287.

Wang, H., Sui, Y., Luthans, F. D., Wang, D. ve Wu, W. Y. (2014). Impact of authentic leadership on performance: Role of followers' positive psychological capital and relational processes. Journal of Organizational Behavior, 35(1), 5-21.

Xiong, H. ve Fang, P. (2014). Authentic leadership, collective efficacy and group performance: an empirical study in China. Social Behavior and Personality, 42(6), 921-932.

Yeşiltaş, M., Kanten, P. ve Sormaz, Ü. (2013). Otantik liderlik tarzının prososyal hizmet davranışları üzerindeki etkisi: konaklama işletmelerine yönelik bir uygulama. İstanbul Üniversitesi İşletme Fakültesi Dergisi, 42(2), 333-350.

Zubair, A. ve Kamal, A. (2015). Authentic leadership and creativity: mediating role of work-related flow and psychological capital. Journal of Behavioural Sciences, 25(1), 150-171.

\section{Kaynakça Bilgisi / Citation Information}

Demiryumruk Dikici, B.. (2020). Günümüzün dijitalleşen işletmelerinde yeni liderlik ve motivasyon modelleri üzerine karşılaştırmalı bir araştırma. OPUS-Uluslararası Toplum Araştırmaları Dergisi, 15(26), 4185-4207. DOI: 10.26466/opus.699386 